\title{
THE CRISIS IN WORK INJURY COMPENSATION ON AND OFF THE RAILROADS
}

\author{
Jerome PoLIACK*
}

The running battle between the Federal Employers' Liability Act $^{1}$ and workmen's compensation calls for a long overdue evaluation of two opposing systems of work injury compensation-both seriously defective today. For nothing less than a crisis pervades work injury compensation in America on and off the railroads. After almost half a century, the Liability Act must be acknowledged as an unsuccessful attempt to evolve a satisfactory compensation system on the basis of the ancient retributive responsibility of the master for damages to his servant. It has led railroad workers into a blind alley. Its central doctrine is deficient; its administration is even more faulty. It operates in a harmful climate, distributing capriciously and improperly awards that are generally insufficient. At the same time, the workmen's compensation laws which cover most other workers have, with few exceptions, declined dangerously; ${ }^{2}$ an essentially valid approach is failing in performance-distributing its benefits perhaps more wisely but also inadequately, thus offering insufficient security to the covered workers and little hope of improvement for railroad workers.

Conflicting proposals for "reform" are being advanced; some pointless, some progressive, some retrogressive, some dangerous. It has been proposed that railroad workers should come under state workmen's compensation laws; ${ }^{3}$ that they should be covered under a federal workmen's compensation law; ${ }^{4}$ that workmen's compensation should be provided but as an elective remedy in addition to the Liability Act; ${ }^{5}$ that negligence suits should be revived for workers in other industries now covered by workmen's compensation, ${ }^{6}$ and many specific proposals have been made

* B.S. 1940, College of the City of New York. Consultant, Social Security Department of the UAW. CIO. Member of the Workmen's Compensation Committee of the President's Committec on Employment of the Physically Handicapped. Statistician, Railroad Retirement Board, Office of Dircctor of Rescarch, 1942-1949. Major author of Work INJURIEs IN THE RAILroad INDUSTRx, 1938-40 (1947). Contributor to legal, economic and sociological periodicals.

${ }_{35}$ Stat. 65 (x908), as amended, 45 U. S. C. $\$ \$ 51-60$ (1946).

- See Worknen's Compensation-A Story. of Failure, Economic Outlook, Jan., 1952.

${ }^{3}$ See resolution of the American Bar Association, 74 A. B. A. REP. 108 (1949).

'For a compilation of bills proposing a federal workmen's compensation law for the railroad industry and for a discussion of criteria for a federal compensation law see Pollack, Workmen's Compensation for Railroad Work Injuries and Diseases, 36 Connell L. Q. 236 (1951).

'See policy statement of the Railway Labor Executives' Association, which represents about 80 per cent of railroad employees, in Labor and Transportation, Program anp Objectives of Transportation Labor in the Post-War Period 39 (May, 1946). This statement reads in parts:

Railroad labor has advocated and recommended an elective system of bencfits for railroad workers to meet the hazards of industrial diseases and railroad accidents. There is no federal system and employees engaged in interstate commerce are not covered by the several state workmen's compensation acts. The establishment of adequate protection should not be further delayed.

'See 5 NACCA L. J. 16 (1950). 
for amending workmen's compensation laws and the Liability Act. To evaluate these divergent proposals and to chart a valid course in a field full of pitfalls, an examination of compensation fundamentals is needed. ${ }^{7}$ Let us therefore review the tort-liability-workmen's compensation controversy and consider how both types of law are meeting their basic problems-how they establish eligibility for compensation, how they are enforced and administered, and how adequate and equitable are their awards.

I

\section{The Running Battle Between Tort Liability and Workmen's Compensation}

The common origin of both systems of compensation was the establishment of a definite employer responsibility for damages to his servant. It meant a great advance in the status of the employee-the introduction of at least a theoretical equality between employer and employee-and was the prerequisite for any equitable approach to compensation. A double standard in the penalties of master and servant for torts to the other had been the rule in antiquity. ${ }^{8}$ A slave could be tortured and even put to death at the discretion of the master. ${ }^{9}$ Plato proposed to quit the master of the homicide of his slave if he merely underwent purification. ${ }^{10}$ Early common law appears to have been far more concerned with the master's liability for damage done by a servant to others than with damage to the servant or slave. ${ }^{11}$ Obscurity clouds the exact origins of tort liability compensation, ${ }^{12}$ presumably because of the prevailing illiteracy of one of the parties, while the other probably had grounds for reticence. It is likely that the master may have been made liable for a more equitable redress of wrongful injuries to his servant in various countries. This development has been found in early Germanic law, ${ }^{13}$ it may also have occurred under the Roman Empire as plebeian grievances were more forcefully asserted. It is clear that this doctrine found its way into English common law and was subsequently brought over to this country. ${ }^{14}$

Pre-industrial compensation under the common law was not called into intensive application nor were its results well enough known to be evaluated. With the Industrial Revolution, however, as work injuries became commonplace, especially on the railroads, the common law was found wanting. It was not enough to prescribe equitable principles in adversary actions against the employer. As Marshall

${ }^{7}$ This need was recognized by President Hill of the International Association of Industrial Accident Boards and Commissions who recommended an international conference on the revision of workmen's compensation laws in his presidential address to the r95 $\mathrm{x}$ convention of the Association. The recommendation was adopted. In Workmen's Compensation Problems, U. S. Bureau of Labor Standards Bull. No. 156, 8, 180 (1952).

${ }^{3}$ Sec THe Holy Bible, Exodus $2 \mathrm{I}$ : 20, $2 \mathrm{I}$.

- For a discussion of this point see 2 James Kent, Commentaries on American Law c. 32, at 260 (7th ed, 1851 ).

${ }^{10} \mathrm{IX}$ Laws 865; in Diazogues of Plato 6II (Jowett transl.).

${ }^{11}$ See KENT, op. cit. supra note 9, at 279.

19 Arthur Lnrson, The Law of Workmen's Compensation 24 (1952).

${ }^{13}$ Id. at 23 .

16 Id. at 25; Walter F. Dodd, Administration of Workmen's Compensation c. I (1936). 
Dawson has commented; "The Bible speaks of a lion and a lamb lying down together. The passage does not say 'side by side' so there is the possibility that one of them may have been inside the other." ${ }^{15}$ To equalize the inherent disadvantages experienced by the disabled in bringing legal action against the employer, administrative and enforcement procedures were needed to help them secure their remedy under the law and to insure the availability of awards where due. Quite the reverse occurred, however, as special barriers were erected in nineteenth century England and America which insulated the employer against liability. In all probability the full implications of the equitable principles that had been adopted earlier were in advance of the actual mores of the time. "The three wicked sisters of the common law"16 - the fellow-servant, assumption-of-risk, and contributory-negligence defenses -were one-sided ground rules for the contest between master and servant which reflect poignantly the underprivileged status of the early industrial worker.

The next great advance was the rise of workmen's compensation. Born in a period of unrest, it was one of a series of social reforms in Germany. Its siblings were sickness insurance, ${ }^{17}$ and old age and invalidity insurance. ${ }^{18}$ It acceptance throughout the world was rapid ${ }^{10}$ and overwhelming-by 56 countries abroad $^{20}$ and by all 48 states, as well as most federal and territorial jurisdictions of the United States. ${ }^{21} \mathrm{~A}$ workmen's compensation law for employees of the Federal Government was approved on May 30 , $1908,{ }^{22}$ one month after tort liability continued to be prescribed for railroad workers under the Liability Act.

Workmen's compensation was a much needed reform. In it, for the first time, society met the problem of actually assuring the remedy. Workers were generally required to give up their entitlement under the common law to restoration of full damages which included, at least in theory, the entire wage loss and other elements of indemnification, but was payable only if the employer was negligent. In return, every worker suffering an occupational disability was to be assured medical and restorative services and cash benefits to replace a major percentage of the loss of wages or of earning capacity. This is a modest standard of security against occupational disabilities. Without it, to work in even the least hazardous employment is to assume economic risks that should not be required of any person.

\footnotetext{
${ }^{16}$ Dawson, Present Conditions of Workmen's Compensation Laws and Possible Changes, in Workmen's Codppensation Problems, U. S. Bureau of Labor Standards Bul. No. 142 60, 66 (1951).

${ }^{16}$ Prosser on Torts c. I2, at 520 (I94X).

${ }^{27}$ Enacted in 1883 , the year before workmen's compensation was first adopted.

18 r889.

${ }^{18}$ By the turn of the century, workmen's compensation had spread to Austria ( 1887 , including Czechoslovakia), Norway (1894), Finland (1895), Great Britain (1897, including Ireland), Italy, Denmark, and France (x898). By 1908, when the Federal Liability Act was passed, workmen's compensation had also been adopted by New Zealand (I900), Sweden and The Netherlands (I90r), Luxcmbourg (1902), Belgium and Russia (Ig03, including Latvia, Lithuania, and Estonia), Guatemala (1906), and Hungary (1907).

20 Soctal Security Legislation Throughout the World, Social Security Administration, Diviston of Research and Stattstics, Bureau Rep. No. i6 4, ro6-14i (1949).

${ }^{21}$ Alaska, Hawaii, Puerto Rico, District of Columbia, U. S. Civil Employees, Longshoremen, and Harbor Workers.

${ }^{22} 35$ STAT. 556 (1908).
} 
For the doubly hazardous railroad industry ${ }^{23}$ a different course was chosen-to reform the common law by abrogating or modifying the employers' defenses-an approach copied from England's short-lived employers' liability act which had been abandoned in $1897 .{ }^{24}$ In effect, the liability act attempted to reverse partially, Lord Abinger and Justice Lemuel Shaw in Priestly v. Fowler ${ }^{25}$ and Farwell v. Boston \& Worcester Railway. ${ }^{26}$ Looking specifically at the steam railways, Congress recognized the anachronism of the fellow servant rule conceived by Lord Abinger on the basis of a master's relations to his "harness-maker," "coachman," "footman," "chambermaid," and the like. ${ }^{27}$ It gave belated recognition to the complex, corporate nature of railways in abolishing this rule, through which employers had escaped liability by assigning the blame for the proximate causation of the injury to another employee. ${ }^{28}$ It modified the palpably inequitable doctrine of contributory negligence so that it no longer bars recovery but reduces damages in proportion to the negligence attributable to the employee. ${ }^{29}$ The Act, however, retained the ancient penalty basis of the employer's responsibility for damages; the ground on which an injured employee or a personal representative on behalf of his survivors must seek to recover damages is the common law rule of negligence.

It would have been naive to expect that an equitable basis for compensation would result from the mitigation of the special employer defenses while the inherent advantages of master over servant were permitted to remain unmodified. The three wicked sisters were themselves symptoms of the inherent inequalities, not their cause. ${ }^{30}$ Despite the statutory reforms which make up the Liability Act, negligence is not a proper basis for compensation. Its nebulous meaning; the denial of recovery where the employer cannot be proved negligent; and the reduction in compensation where the employee was partly to blame, do not give covered workers the security that a remedy will be theirs if injured. In addition, the Act's administration usually through individual bargaining out of court-an unsupervised contest between unequal parties; the uncertain and capricious allocation of awards, with prodigal rewards for a few, negligible amounts to many, and inadequate indemnification for the majority; the long, anxiety-laden delays in settlement; the diversion of large amounts for litigation expenses; the focus on a release of liability rather than a proper remedy; the almost total neglect of rehabilitation as a process not

${ }^{23}$ The severity rate of railroad employee injuries was found to be twice that of all manufacturing in 1938-40. See Railrond Retirement BOARD, WORK INJURIES IN THE RAILroAd INDUSTRY, I938-40 59 (1947). This two-volume study will be referred to hereinafter as Work INJurues.

is Sce Walter F. Dodd, Administration of Wórkmen's Compensation 16, I7 (1936).

${ }^{25} 3$ M. \& W. 1, 150 Eng. Rep. r030 (Ex. 1837). E. H. Downey, in History of Work Accident INDEMNITY IN IOWA 239 (1912) commented on Lord Abinger's opinion: "Had the learned and antiquated Lord drawn his analogies from the factories or steam railways then flourishing. all about him, his arguments might have seemed less conclusive even to himself." I am indebted for this quotation to Dopd, op. cit. supra note 24 , at 5 .

20.4 Metc. 49 (Mass. I842).

${ }^{27} \mathrm{See}$ Dodd, op. cit. supra note 24 , at 4,5 .

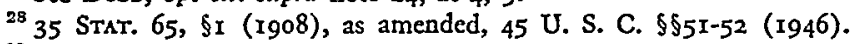

$20 \mathrm{Id}$. at $\$ 3$.

${ }^{30}$ The metaphor recalls the three witches of Macbeth who likewise were symptoms, not causes, of Macbeth's ambition. 
originally contemplated in the principle of damages; do not exhaust the deep-seated deficiencies which disqualify the Liability Act as a proper method of compensation.

Workmen's compensation brought immediate gains but, in time, a different set of deficiencies. Progress has been made toward an orderly handling of the problem and payment has been made relatively certain, reliable, and prompt. The central concept of workmen's compensation has been one of social responsibility and it has led to the beginnings of a rehabilitation program of great potential value. But the gains are soon exhausted. Little has been done to keep alive the vision and high purpose which animated the rise of compensation laws. A harmful rigidity and restrictiveness have taken over, as the arena in which bargaining for compensation occurs was switched to the state legislatures where there has been no dearth of spiritual heirs to Lord Abinger. Unduly low levels of compensation, rigid dollar maximums, improper duration maximums, unwarranted exclusions, and even absurdities have contributed to their present decline. ${ }^{31}$ No attempt should be made to belittle the shortcomings of many state compensation laws. To do so in the spirit of controversy would oversimplify the issues and obscure perhaps the principal reason why railroad workers today do not have a workmen's compensation lawtheir belief that they would not have fared any better. Actually, it is far from certain that the railroads are repaying an appreciably greater percentage of work injury losses than other employers under workmen's compensation. Defective state laws, moreover, are not the necessary alternative to the FELA, nor are their present shortcomings inherent features of workmen's compensation. Certainly this belief could not be held in the face of a proper workmen's compensation law which would not only increase substantially the total amount of compensation to railroad workers, but distribute it far more equitably. Nevertheless, while this argument does not actually support the FELA, it effectively discourages the search for alternatives.

How much longer railroad workers can afford to accept dubious "proofs" that they are better off ${ }^{32}$ in lieu of a sound compensation system remains to be seen. The entire field of compensation has long been enveloped in neglect, indifference, and apathy. Railroad workers face two problems where other workers face one. Both need a substantial increase in compensation; in addition, the railroad workers need the assurance that every worker will receive an equitable remedy, an assurance that can come only from an affirmation and strengthening of workmen's compensation and the abandonment of negligence as the basis for compensation.

II

\section{BASIS FOR COMPENSATION}

\section{A. Negligence}

Once the doctrine that industry should insure the safety of all employees

\footnotetext{
${ }^{s 1}$ For a more complete discussion of the inadequacies of state workmen's compensation, sec Pollack, Labor Looks at Workmen's Compensation, in Workmen's Compensation Problems, U. S. Burent of LABOR StANDARDS BuLl. No. I56 I 40-157 (1952).

${ }^{32}$ See Richter and Forer, Federal Employers' Liability Act-A Real Compensatory Law for Railrond Workers, 36 CORNELL L. Q. 203 (195I).
} 
gained currency, it was bound to confute the more restrictive notion that the employer's responsibility should be confined to injuries caused by his negligence. Supporters of the Liability Act rarely claim that negligence is a proper basis for compensation. Instead, they contend that a "new trend"33 is developing under the FELA under which negligence is being construed more liberally as a result of the depersonalization of negligence, effective use of the doctrine of res ipsa loquitur, de-emphasis of proximate cause, abandonment of assumption of risk, a tendency to upset unfairly secured releases or compromises, and the like, resulting in a form of enterprise liability approaching a state of negligence without fault. ${ }^{34}$

Such claims must be carefully appraised. At the outset, it should be pointed out that except for the abandonment of assumption of risk, these claims are not new. At least as early as 1905 , very soon after the fellow servant defense was abolished in some state jurisdictions, it was claimed that "the mere proof of a collision would raise the presumption, in the absence of other explanation, that the injury was due to a breach of duty owing to the plaintiff and his right to recover would be the same as if he had been a passenger." ${ }^{35}$ This reform had still to be won in $193^{8-40 \text {, }}$ the period investigated by the Railroad Retirement Board. The same can be said for the other claimed trends. As evidence that these "new trends" had culminated in a satisfactory act, one author claims: "When the 1939 amendment to the Employers' Liability Act was adopted, the railroad brotherhoods testified that the amendment met their needs and that they were satisfied with it." ${ }^{36}$ The FELA could not by any conceivable standard have been regarded as satisfactory in 1939 . The Railroad Retirement Board's investigation leaves no possible doubt as to the state of the FELA at that time.

Some modifications in the meaning of negligence were, of course, inevitable. Viewed as a personal dereliction of duty, employer negligence would soon have become utterly meaningless. Obviously, the carrier's duty to its employees had to be re-defined in institutional rather than personal terms. Likewise, a narrow construction of proximate cause had to be modified as large scale operations made it increasingly difficult to trace and quantify the respective negligence of master and servant with respect to each injury. Also, the doctrine of compensation regardless of fault was bound to have some impact even on practices under negligence-oriented law. But the carrier's responsibility under the FELA has always been limited to the exercise of ordinary care and prudence to provide a safe working place and safe tools and appliances. From the beginning, the Supreme Court has stressed that the employer is no guarantor of the employee's safety beyond the exercise of due care and prudence. $^{37}$

${ }^{33} \mathrm{Id}$. at 231.

34 Aldert A. Ehrenzweig, Negligence Without Fault (ig5i).

35 I Thomas G. Sherman and Amasa A. Redfield, A TreatTse on the Law of Negligence 445 (19lis).

${ }^{30}$ See Richter and Forer, supra note 32 , at 233 and n. 114 . It would appear from the citation that the railroad brotherhoods approved only the specific amendments, not the entire act as such.

${ }^{37}$ Seaboard Air Line Ry. v. Horton, 233 U. S. $492\left(19 x_{4}\right)$. 
It is this interpretation of negligence which demonstrates the futility of the attempt made in 1939 to eliminate by legislation the assumption of risk defense. The Supreme Court in Tiller v. Atlantic Coast Line Ry. ${ }^{38}$ has stated that the 1939 amendment was intended to release "the employee from the burden of assumption of risk by whatever name it is called. The result ... required cases tried under the Federal Act to be handled as though no doctrine of assumption of risk had ever existed...."

Despite the amendment and this forceful language, doubt still remains as to whether recovery in full is possible under conditions in which this defense used to be pleaded. Assumption of risk is readily transformed into a denial of negligence on the ground that the risk is one normally incident to the occupation-especially in those cases where the management followed a traditional method of operation well known to employees. Reports received by the Railroad Retirement Board covering the periods preceding and following the amendment clearly indicate this tendency to convert assumption of orisk into a denial of negligence. ${ }^{30}$ Assumed risk can also be construed as contributory negligence; although, for example, the employee's continuing in employment despite knowledge of employer negligence can no longer be called assumption of risk, it may be regarded as contributory negligence and recovery would be impaired only through the operation of the comparative negligence rule.

An employer is thus without fault under the FELA if he follows general practices and safety standards in the industry. He is not required to eliminate unsafe working conditions or introduce new safety devices if the conditions of work and equipment are no worse than those which prevail in the industry. It is not enough to issue a proclamation that the assumption of risk plea will no longer be heeded. Its complete abolition evidently awaits the abandonment of negligence.

The meaning of negligence, always nebulous, has, to say the least, become confused and supporters of the FELA are taking advantage of this confusion to claim sweeping reforms. At times they have gone so far as to assert that employer negligence can be established in virtually every injury, ${ }^{40}$ although this is not confirmed by established fact.

Every study of payments under the FELA has brought to light a considerable

${ }^{38} 3$ I8 U. S. 54 (r943).

392 WORK INJURIEs, op. cit. supra note 23 , at Table E-5.

${ }^{10} \mathrm{~S}$. C. Lush, former manager of the Brotherhood of Railroad Trainmen Legal Aid Department, illustrates this point in an address:

I have been connected with ... the Legal Aid Department for over 25 years and I am, therefore, in a position to speak to you in regard to the number of employees in train and yard service who are injured as a result of the fault of the railroad company. I think we can safely say that 99 percent of the injured men I have heard of were injured through the fault of the railroad company and that the company was legally liable, if you were able to establish those facts. The Railroad Trainman, Jan. 1947, p. 9.

Efforts by the Brotherhood of Railroad Trainmen to increase the review of cases by establishing a legal aid bureau, with attorney fees restricted to a below-average percentage of the award, appear to have had only partial success in increasing resort to attorneys by its members but no appreciable effect in increasing the per cent of cases brought to or adjudicated by the courts, according to an unpublished survey made by the author in connection with the Work INJurIes report. 
number of cases in which employer responsibility was not established, as indicated by settlement without payment or for a negligible amount. ${ }^{41}$ True, the most recent data relate to settlements made over a decade ago but these payment patterns are so deeply imbedded in liability practice and have prevailed for so long a time, that it is inconceivable that they have become obsolete even with a rise in the general level of payment. Taking first the ultimate in severity of injury, those resulting in death, out of a total of $5^{26}$ fatal injuries in which the employee was survived by a widow and/or children in as many as Ig cases no payment at all was made-all of them "settled" under the Liability Acts. Another I 6 families received only a burial allowance of $\$ 500$ or less, and scarcely more tangible was the railroad admission of liability to another 45 families who received only $\$ 501$ to $\$$ r,000. ${ }^{42}$ A similar recital could be repeated for every type of disability. To be aware of this record makes it difficult to accept unsupported assertions or speculations that railroads are insuring all of their employees under the Liability Act.

Justice Black, delivering the opinion of the Supreme Court in Wilkerson $v$. $M c$ Carthy, $^{43}$ issued a much needed reminder:

There are some who think that recent decisions of this Court which have required submission of negligence questions to a jury make, "for all practical purposes, a railroad an insurer of its employees" ... This assumption ... is inadmissible. Its rests on another assumption, this one unarticulated, that juries will invariably decide negligence questions against railroads. This is contrary to fact. ...

Finally, to dispel any illusions that the negligence-motivated system of compensation has been successfully overhauled, we have the forceful statement by Justice Frankfurter in $1949:^{44}$

The difficulties in these cases [suits under the Federal Employers' Liability Act] derive largely from the outmoded concept of "negligence" as a working principle for the adjustments of injuries inevitable under the technological circumstances of modern industry. This cruel and wasteful mode of dealing with industrial injuries has long been displaced in industry generally by the insurance principle that underlies workmen's compensation laws. For reasons that hardly reflect due regard for the interests of railroad employees, "negligence" remains the basis of liability for injuries to them. It is, of course, the duty of courts to enforce the Federal Employers' Liability Act, however outmoded and unjust in operation it may be. But so long as negligence rather than workmen's compensation is the basis of recovery, just so long will suits under the Federal Employers' Liability Act lead to conflicting opinions about "fault" and "proximate cause." The law reports are full of unedifying proof of these conflicting views, and that too by judges who seek conscientiously to perform their duty by neither leaving everything to a jury nor, on the other hand, turning the Federal Employers' Liability Act into a workmen's compensation law.

¿1 I Report of the (Sutherland) Employers' Liability and Workmen's Compensation Commission, Sen. Doc. No. 338, 62d Cong., 2d Sess. (I912). Cost of R'ailroad Acctdents, i932, Sen. Doc. No. 68, 74th Cong., Ist Sess. (1936). Work INJURIEs, op. cit. stupra note 23.

42 WORK INJURIEs, op. cit. supra note 23 , at Table C-I 4.

336 U. S. $53,6 \mathrm{I}-62$ (r949).

44 Id. at 65-66. 


\section{B. Insurance}

As a standard for entitlement to protection, the superiority of workmen's compensation over the FELA would normally be beyond dispute. While the FELA requires an assessment of liability to be made in each injury and expressly excludes cases determined or believed to be non-negligent, workmen's compensation endeavors to offer "sure and certain relief."

In practice, however, the difference between the two approaches, though considerable, is far from absolute. The usual dual test of compensability-covering injuries "arising out of and in the course of employment" rigid. It has often been interpreted too narrowly, barring disabilities which were employment-originated by reasonable standards (although at other times it has been construed with such looseness as to invite the despair of those who value an orderly approach to compensation). To obviate the early constitutional objections to a compulsory law, many compensation laws permit employers to choose whether or not they wish to come under the law; in at least 26 states the present workmen's compensation laws are elective. ${ }^{47}$ Occupational disease has not been adequately covered in a number of states. Disease coverage has been approached fearfully and reluctantly, without proper recognition that occupational disease has an equal claim to compensability with that of any other occupational injury. Five states do not cover occupational diseases at all ${ }^{48}$ and one state covers only silicosis. ${ }^{40}$ Seventeen states $^{50}$ cover only lists of specified diseases, although such lists are often out of date or exclude arbitrarily diseases which arise out of employment. The requirement of violent trauma has resulted in failure to cover cases in which personal injury was sustained without a history of specific incident or violent accident. There has also been a continuation or resurgence of negligence concepts under workmen's compensation. Misconduct, vestiges of employer or employee fault, have occasionally been retained or re-introduced as barriers to recovery or calling for special penalties.

If workmen's compensation has offered something less than a magic portal to compensability, it has expanded greatly the entitlement to compensation. In contrast to the complete denials of a remedy under the FELA, the Railroad Retirement Board did not find a single case of a widow or child or permanently and totally disabled worker dismissed without payment under workmen's compensation laws. ${ }^{61}$

\footnotetext{
${ }^{15}$ Washington Workmen's Compensation Act, Wasf. Rev. Stat. ANN. \$7673 (1932).

40 See Samuel B. Horovitz, Injury and Death Under Workmen's Compensation Lnws $93-182$ (1944).

${ }^{47}$ Alabama, Colorado, Connecticut, Florida, Georgia, Indiana, Iowa, Kansas, Louisiana, Mainc, Missouri, Montana, Nebraska, Nevada, New Jersey, New Mexico, North Carolina, Oregon, Pennsylvania, Rhode Island, South Carolina, South Dakota, Tennessee, Texas, Vermont, West Virginia. This listing refers primarily to election by employers. It excludes employee elections and numcrous clective provisions affecting exempted employers and employments.

${ }^{48}$ Kansas, Louisiana, Mississippi, Oklahoma, and Wyoming.

¿o Alabama.

${ }^{50}$ Arizona, Colorado, Georgia, Idaho, Iowa, Kentucky, Maine, Maryland, Montana, New Hampshire, New Mexico, North Carolina, Pennsylvania, South Dakota, Tennessee, Texas, and Virginia.

512 WORK INJuries, op. cit. supra note 23 , at Tables C-15, C-rg.
} 
Moreover, on the basis of present experience few obstacles, either in the matter of legal draftsmanship or administrative technique, would stand in the way of providing for a sure and certain remedy for railroad workers under a workmen's compensation law specifically designed for them.

\section{III}

\section{ENFORCEMENT}

A. Under the FELA

Regarded historically, it was perhaps natural for the FELA to have retained the methods of enforcement that had been employed by the common law. From the standpoint of social policy this was a major mistake. The administrative and procedural shortcomings of common law compensation were by far its most grievous fault. Yet the framers of the FELA addressed themselves to a few reforms in the entitlement provisions and left the procedure essentially unchanged..$^{\mathbf{2}}$

Although the administrative shortcomings of the FELA have been described before ${ }^{53}$ they have received so little recognition as to warrant restatement.

The liability law is little more than a broad statement of principles whose application to specific injuries is often very remote. The only agency empowered to enforce the respective rights of employer and employee is the court. Resort to the courts, however, is beset with so many barriers for the employee and pitfalls for the carrier that it is avoided wherever possible. ${ }^{54}$

Employees are afraid to "start trouble" with the employer. They fear in a manner against which legal, ${ }^{55}$ contractual $^{56}$ and verbal ${ }^{57}$ assurances are evidently of little avail, that filing suit or even hiring an attorney might jeopardize job tenure for themselves or for other family members; and fellow employees who may be witnesses may share the same concern. Moreover, anxiety over future employment is likely to be almost always present where return to the same job is no longer possible and the employee hopes to secure a lighter job ${ }^{58}$ from the employer.

¿2 The only provisions of the Act bearing on its enforcement are that an injured employee or survivor may bring action in a federal or state court within three years from the date of injury. 35 STAT. 65 (I908) at \$6. The Act, however, voids any contract, rule, regulation or device whose purpose is to cnable the carricr to cxempt himself from liability under the law. Id. at \$5. Such a rule or device, etc., may not be used to prevent an employee from furnishing information to an interested party as to the facts incident to the injury or to the death of a fellow employee. Id. at $\$ 10$.

${ }^{3}$ See I WORK INJURes, op. cit. supra note 23, c. 4, at 35; Pollack, supra note 4, at 240; and Sutrerland Commission Report, op. cit. supra note $4 \mathrm{I}$, at 87 .

"For a full discussion of this problem, see I WORK INJuries, op. cit. supra note 23, c. 4 .

Et See note 52, stipra.

${ }^{0}$ Under collective bargaining contracts an employee may not be dismissed except for good cause. See also note 58 , infra.

${ }^{\text {"7 }}$ See, for example, Are You Afraid of the Claim Agent?, The Railroad Trainman, Oct. 1943, p. $364 ;$ reprinted by request, January 1946, p. 14. Despite the many assurances and safeguards, the Railroad Retirement Board found that according to the accounts of injured employees the belief that to bring a claim to court is to invite dismissal was widespread and that such threats were used in dissuading employees from filing suit or engaging an attorney. Moreover, confirmation that actual practice justified such fears was demonstrated statistically in an analysis of actual returns to work in relation to whether an attorney had been hired or the case entered in court. See I Work INJuries, op. cit. supra note 23, at 37 .

${ }^{58}$ Collective bargaining contracts usually protect the worker's right to return to the same job but do 
As the injured employee may have to rely on the settlement as the major source of income for life, he is also bound to be reluctant to surrender one fourth or one third-and in one out of eight non-fatal cases, half or more ${ }^{50}$-of his settlement to an attorney and to reconcile himself moreover to the augmented delay involved in litigation. ${ }^{60}$

Only a small number of claims are negotiated by attorneys on behalf of the claimant $^{61}$ or are brought to court. Even where suit is filed, in the majority of cases, the claim is settled long before court action is completed. Only 16 per cent of the permanent total, 8 per cent of the fatal, and 4 per cent of the major permanent partial-disability claims are actually adjudicated by the courts. For claims arising from less severe injuries, courts pass judgment on considerably less than one per cent. $^{62}$

In one sense it is not feasible for the courts to deal with more than a minute fraction of work-injury claims. On the other hand, because of the broad language used in the Liability Act, it is not conceivable that it can be properly administered except by a body of impartial men versed in the fine points of the law and skilled in the careful sifting and analysis of evidence.

The great majority of severe injury claims and practically all minor cases are settled by a bargaining process far removed in spirit from the few brief paragraphs which make up the Liability Act. The injured employee usually acts alone or occasionally is assisted by a trade union agent; the railroad on the other hand is represented by an attorney well versed in the law and in the fine art of adjusting claims by a skillful combination of threat, persuasion, and pressure. While the employee conceives of his case individually and, as a result of interrupted or severed income, is often hard put to maintain his family until the case is settled, the railroad claim department approaches the claim in the light of the well defined procedure which is its business and has vastly greater resources with which to process its case.

Usually a series of offers is made, each coupled with pressure to secure its acceptance, each tendered as the very last one that will be made-presumably strain-

not assure entitlement to a lighter job when he is unable to fulfill the requirements of the job to which his seniority entitles him. In the railroad industry this problem may be compounded by the possible need to cross union lines to secure a job that the handicapped employee may be able to perform. Thus when the worker thinks about a lighter job he often feels it to be advisable to take a "cooperative" attitude in dealing with the employer.

${ }^{50}$ I WORK INJURIEs, op. cit. supra note 23 , at 39-42.

${ }^{\circ 0} \mathrm{Id}$. at 152-155. The results showed that an employee with a major permanent partial impairment stands a better than even chance of settling his claim within 6 months if he does not go to court or hire an attorney. If he files suit, however, the probability is only one in four that the claim will be closed within a half year; in two out of five cases it will still be unsettled at the end of a year. Employecs do not hire counsel in four out of five cases, until they have received an initial offer which they regard as too little to offer hope of a satisfactory settlement. On the average they wait from 5 to 9 months before hiring an attorney.

${ }^{11}$ Id. at 44.

${ }^{62}$ Id. at 45 . These specific percentages are cited from the findings of the Railroad Retirement Board's investigation, but the fact that courts adjudicate only a negligible fraction of the claims has becn truc ever since the inception of the Liability Act as shown by the findings of the Sutherland Commission Report and the study made by the Federal Coordinator of Transportation. See note $4 \mathrm{r}$, supra. 
ing the bounds of generosity-and with the proviso that it must be accepted within a specified time or it will be withdrawn.

The workings of the bargaining process are revealed by a typical case cited in the Railroad Retirement Board's report Work Injuries in the Railroad Industry: ${ }^{83}$

A carman [was] fatally injured in the employ of a large western road in November, 1939. He left a widow aged 6r, a daughter aged $\mathrm{I}_{5}$ and a son aged $2 \mathrm{I}$. The case was not settled until July, 1940, when $\$ 5,000$ was paid. In the meantime, the following offers were made by the road: $\$ x, 000$ in the middle of December, $1939 ; \$ 2,000$ five days later; $\$ 3,000$ in February, I940; $\$ 4,000$ in April, I940 and finally $\$ 5,000$ in July, I940.

A question naturally arises as to the reason for beginning with an offer of $\$ 1,000$ if a liability to the extent of $\$ 5,000$ was finally admitted. The Retirement Board went on to say:

The man died within a few hours of the accident, and the first offer was made about a month after that; a period long enough for the company to have established the circumstances under which the accident occurred, the number and age of surviving dependents, and all the other factors relevant to the determination of the correct amount due. Another question is equally pertinent: What would have happened if the widow, in need of funds and distraught by the sudden misfortune, had accepted the first offer or, for that matter, any of the intermediate offers? If $\$ 5,000$ is the proper payment, then anything less than that would have deprived the survivors of what was, in effect, a debt owed them. And finally, how much larger would the payment have been if the widow had wished to hold out longer and could have done so?

Promptness of payment is an early casualty in this kind of negotiations. Under the circumstances, a prompt settlement is likely to be made at the risk of an insufficient award. On the other hand, in a period of interrupted income, uncertainty, and anxiety about the future, the employee is in no position to prolong the outcome unduly and delay is, in fact, a more potent weapon in the hands of the claim agent. ${ }^{64}$ The Railroad Retirement Board found that nearly half of the more seriously injured employees had to wait more than half a year before they received any payment at all under the Liability Act and many waited two or three years. ${ }^{65}$

The administrative costs of such a compensation system are excessive, ${ }^{66}$ amounting to 26 per cent of the gross cash payments to the injured and their families and 29 per cent of the net cash payments. Most of this expenditure, while understandable within the framework of the liability system, is actually duplication and waste.

The ultimate administrative deficiency of the Liability Act is to be seen in the

${ }^{03}$ I Work INJuries, op. cit. supra note 23 , at $48-49$.

" Employees interviewed by the Railroad Retirement Board were quite outspoken about the adverse effects of delay on their claims. One worker who received a rather generous settlement (having raised the payment in the course of bargaining from an initial offer of only $\$ 50$ five months after the injury, to an offer of $\$ 550$ three months later, and finally $\$ 1,500$ after another three months), commented that the settlement was well within the bounds of decency but added that he would have regarded it as more than fair if the $\$ I, 500$ offer had been made at the start, instead of "prolonging the case and trying to starve me out."

of I WORK INJURIES, op. cit. supra note 23 , at 155 .

${ }^{\text {as Id. at }} \mathrm{I80}$. This remains true despite the Conard and Mehr Study, infra, note 7x. 
pattern of payments. The threat of exceedingly large awards which are occasionally paid sets into motion countervailing forces to resist compensation, case by case, and thus generates a climate in which the jackpot is counterbalanced by numerous cheap releases at the expense of the uninformed, the unprotected, and the unlucky. This is, of course, the reason for beginning with a $\$ 1,000$ offer in a case that might be settled for $\$ 5,000$ and might conceivably run to $\$ 100,000$. In such an atmosphere, the possibility of a sound policy toward the problem is perhaps hopelessly lost.

\section{B. Under Workmen's Compensation}

It would be too much to expect workmen's compensation to have overcome completely these administrative and procedural shortcomings. In the first place, compensation under these laws continues to be determined by a bargaining process, although it is collective rather than individual; public rather than private; and is presumably settled in advance of the injury rather than when the employee is hurt. Political bargaining can easily become too detached in spirit and method to do justice to the disabled. And there are lobbies in the state capitols who can quell with great effectiveness any moves to provide a more adequate remedy. In a political setting the rationale of workmen's compensation often becomes hazy and the benefits which emerge may resemble public assistance rather than an acknowledged right derived from employment. Looking at the statutory benefit maximums of many state laws one is tempted to join in the common feeling that no jury would be likely to award the penurious compensation which many state legislatures have written into law.

Court administration still exists in five states. ${ }^{67}$ Most states provide for the settlement of claims by agreement between the employer and employee with varying degrees of responsibility assigned to the administering agency to approve or review their conformity to the provisions of the law.

One of the most serious deficiencies of several workmen's compensation laws has been a failure to live up to the original intention to make payments virtually automatic so that the volume of litigation would be negligible and claimants would normally not need representation. Instead procedures have become increasingly legalistic and litigious.

On the other hand, it would have been inconceivable for workmen's compensation laws, designed particularly to overcome the administrative evils of common law procedure, not to have made very material progress. Administrative reforms under workmen's compensation have, on the whole, been tremendous. When an employee is injured there is far less pressure on him for a quick release of liability during the period of convalescence. Instead, he has reasonable assurance that he will be compensated and payments in fact generally do begin promptly. ${ }^{08}$ The

67 Alabama, Louisiana, New Mexico, Tennessee, and Wyoming.

68 The Railroad Retirement Board found, for example, that in one fifth of the major permanent partial disabilities, payments under workmen's compensation laws began within 2 weeks, and in more than half of the cases, within a month. By 6 months almost nine-tenths of the employces suffering from this complex type of disability had received compensation. I WORK INJURIEs, op. cit. supra note 23, Table 38 , at 15 r. 
employee has far more assurance that the award will, within the conditions fixed by the law, properly reflect the extent of his injury, objectively determined; and that consequences of the injury that may emerge later will be compensated.

In most states the administrative agency either initiates the award or it must approve all settlements, although approval is often perfunctory. Only in 8 states $^{69}$ is the agency's review restricted to disputed cases and in another 3 it may either investigate agreements or exercise a veto power at its discretion. ${ }^{70}$

Superior administration is the rule under workmen's compensation, although there is vast room for improvement. In some jurisdictions, exemplary administration, virtually litigation-free, is not "a vanished dream"71 but a well established reality.

\section{IV \\ Payments}

\section{A. Under the FELA}

The manner of payment under the FELA has been characterized as a "lottery."72

${ }^{\circ}$ Arkansas, Colorado, District of Columbia, Illinois, Michigan, Mississippi, Montana, and New Hampshire. This listing is based on an interpretation of the statutory provisions. Actual administrative practices often differ from the statutes.

${ }^{70}$ Florida, South Dakota, and Wisconsin.

${ }^{71}$ See Richter and Forer, supra note 32, at 225. Administrative procedures and costs under the Liability Act and workmen's compensation are coming under increasing review. Originally workmen's compensation laws were intended to "Eliminate economic waste in the payments to unnecessary lawyers, witnesses and casualty corporations and the expense and time loss due to trials and appeals." From First Annuni. Report of the Compensatton Comisissioners of the State of Washington, Industrial InSURANCe Department 6 (1912)..

This objective has almost been fully achicved under the Canadian compensation laws. The following is quoted from a letter from The Workmen's Compensation Board of Ontario:

Because of the simplicity of the set-up of our compensation law . . . it is not considered necessary that claimants require the assistance of attorneys to present their claims to the Board. ... it has always been the general policy of our Claims Department to deal with the injured workman directly rather than through anyone representing him. This Board does not object, of course, to attorneys' submitting material on behalf of claimants . . . but we do not feel that it is necessary.

In cases of appeal we have noticed that claimants who disagree with the adjudications of the Board appeal the decision made in their claims through their solicitor . . . Having regard, therefore, to the total number of claims filed with the Board, we would say that the cases where solicitors are hired by claimants to present their claims to the Board are infinitesimal.

The Bureau of Employees' Compensation which administers the Federal Employees' Compensation Act reports that "the percentage of cases in which counsel appears represents only a negligible portion of the total cases . . . counsel is usually obtained only in cases in which the claim may be rejected or the adjudication is otherwise unsatisfactory to the claimant." (Letter.)

On the other hand, the need for administrative reforms under some state compensation laws is indicated by a recent study on the Costs of Administering Reparation for Work Injuries in Illinois by Professors Conard and Mehr, University of Illinois (I952). See also, Conard, Workmen's Compensation: Is It More Efficient than Employer's Liability?, 38 A. B. A. J. Iorx (1952). This study compares administrative costs under the FELA as revealed by WORK INJuRIEs, op. cit. supra note 23, with costs under the Illinois workmen's compensation law as ascertained directly by the authors of the study and their staff. While claimant attorneys were infrequently employed under the Liability Act, the study asserts that they are almost universally employed under the Illinois law-in 90 to 95 per cent of the non-fatal injuries. There is some question as to the accuracy of these findings. Unfortunately, the study implies too ready an acceptance of the high administrative costs under the FELA in making the point that a poorly administered workmen's compensation law could conceivably cost even more to administer. However, this is an important admonition for the faulty compensation laws.

${ }^{72}$ Sen. Doc. No. 68, 74th Cong., Ist Sess. 5, 6 (1936). 
A close investigation into the operation of this lottery yields significant insights into aspects of human motivation which account for the tolerance of a social measure that is unsatisfactory to most of the people with whom it deals, because it is especially generous to a few. There is also a fertile field for research into the effectiveness of vested interests in superseding sound social policy.

The Liability Act does produce some prodigal awards. ${ }^{73}$ The large awards are well publicized. ${ }^{74}$ They have entered the nation's folklore. ${ }^{75}$ They appeal to the gambling instincts of people who generally do not expect to become injured and would like to imagine themselves handsomely rewarded if injury should befall them. They are more appealing psychologically than even the identical amounts expressed as periodic payments and are understandably far more appealing than the limited and niggardly pensions provided under many workmen's compensation laws.

However, the probability of obtaining a generous award under the FELA is small. For every winner there are many losers. Here is how actual payments were distributed in $193^{8-40}$, when every injury occurring in twelve alternate months was tabulated:

For fatal injuries where the worker was survived by a widow and/or children, payments ranged from more than $\$ 20,000$ to nothing. In one out of $50 \mathrm{cases}$, the settlement amounted to ten or more years of full-time wages; but ten times more numerous were payments of less than one year's wages. ${ }^{\mathbf{7 6}}$

One worker who became permanently and totally disabled in the same period received $\$ 50,000$, then the highest gross settlement before attorney fees and other expenses were repaid. Of xio employees so disabled, nine were paid ten or more years of wages. At the same time, one employee who was also totally incapacitated for the rest of his life received nothing and thirteen received less than two years' pay. ${ }^{77}$

Twenty-six employees lost an entire arm in the twelve-month period studied by the Railroad Retirement Board; three were paid less than one year's wages, five from one to two years', two from two to three years', seven from three to four years', and so forth up to one employee who received nine years' pay. ${ }^{\mathbf{7 8}}$

Variability and unpredictability of payment has been characteristic of railroad

${ }^{73}$ See 5 NACCA L. J. 223-235 (1950) and subsequent issues for listings of Verdicts of Awards Exceeding $\$ 50,000$.

74 Newspapers evidently regard it as newsworthy whenever a large award is paid to an injurcd railroad worker. On the other hand, the widows who settle their cases out of court for only three years of their husbands' wages are not likely to issue press releases.

${ }^{75}$ Carl. Sandburg, in The American Songbag (1927) has several songs dealing with railroading. One is entitled Mama Have You Heard the News and speaks knowledgeably about the payments. The first verse begins with the title and goes on:

Daddy got killed on the C-B-and Q's.

Shut your eyes and hold your breath,

We'll all draw a pension upon papa's death.

The song combines an awareness of the availability of the pension with appropriate anxiety in "shut your eyes and hold your breath." Id. at $368,37 x$.

$\mathrm{O}_{2}$ Work Injuries, op. cit. supra note 23 , Appendix C, Table C-16.

${ }^{77}$ Id. Appendix C, Table C-Ig.

${ }^{78} \mathrm{I}$ id. at 128 . 
injury payments under the FELA from the beginning ${ }^{79}$ and of payments under most tort-liability-motivated systems of compensation. ${ }^{80}$ It is a natural consequence of the settlement procedures.

With such a wide spectrum of payments, individual or selected payments lend themselves easily to misinterpretation or misrepresentation. What a typical railroad worker can expect to receive if he should become injured is better indicated by the average payment for each type of disability, a significant measure of the over-all liberality of the system. One of the consistent characteristics of Liability Act payments is that whenever averages are computed of all injuries or all settlements in a period, they turn out to be surprising or shockingly low.

The average gross payment for a fatal injury in I908-Io was $\$ 1,222 .{ }^{81}$ By I932, the valuation of a railroad worker's life had increased to $\$ 4,179,{ }^{82}$ and to $\$ 5,205$ in $193^{8-40 .}{ }^{83}$ The average net payment, after attorney fees were repaid, represented three years of wages in death cases in $193^{8-40}$, where the worker was survived by a widow and/or children. It was still the measure of compensation for the life of husband or father in an unpublished study made by the author of a sample of deaths in I942-3. Although the average payment had by then increased to over $\$ 7,000$ it repaid only 2.7 years of the higher wages of the time. The inadequacy of three years of wages as the total compensation for the death of husband or father is obvious; the Liability Act restored only 27 per cent of the wage losses to the widows and children. ${ }^{84}$

For workers totally and permanently disabled for all employment the average payment was approximately $\$ 12,000,{ }^{85}$ about six years of wages and a restoration of about 60 per cent of the wage losses. ${ }^{86}$ In permanent partial disabilities the payments returned between one-third and one-half of the estimated loss of earning capacity $^{87}$ while in temporary total disabilities about 64 per cent of lost wages were repaid. ${ }^{88}$

In all, employees and survivors involved in injuries received less than $\$ 11,000,000^{89}$ in net cash payments after repaying attorneys, court costs, and other incidental expenses. They received less than 46 per cent of their wage losses ${ }^{90}$ and certainly negligible consideration for pain and suffering, the loss of care and counsel of father and husband, and other elements that are supposed to be part of the damages payable under the Liability Act.

\section{B. Other Aspects of Payment}

The gambling table approach of the Liability Act is revealed by still another feature of its payments. The typical mode of payment is a single lump sum in return for a release of liability. Once the release is signed there is usually little

\footnotetext{
7" See note 4I, supra. $\quad{ }^{80}$ Dodd, op. cit. stipra note 24 , at I9-2r.

82 Sutherland Commission Report, op. cit. supra note 41 ; also note 82, infra.

82 SEN. Doc. No. 68, 74th Cong., Ist Sess. 21 (I936).

${ }^{3}$ I WORK INjuRIEs, op. cit. supra note 23 , at 96 .

${ }^{84}$ Id. at 107 .

${ }^{85} I d$. at II2.

${ }^{80} \mathrm{Id}$. at 6.

${ }^{80}$ Id. at 120.
${ }^{\circ}$ Ibid.

${ }^{87} 1 d$. at 127.

${ }^{80}$ Id. at I39.
} 
chance to reopen cases in which the full extent of disability had been unknown or underestimated at the time of settlement. Nor is there any real concern over how effectively the money is used to replace the losses. Lump sums are often overestimated at the point of settlement; many persons are unaware of the small monthly annuity equivalent of a seemingly substantial sum. ${ }^{91}$ Moreover, the lump sum settlement in the hands of persons unaccustomed to holding and investing money leads to expenditures or investments that often do little to replace the lost income. Even before the settlement can be disposed of, there is often an unexpected volume of expenses which must be repaid-attorney and court expenses; medical expenses and the cost of medical testimony; living expenses and debts accumulated while awaiting settlement; and others. The actual dispositions made of settlement payments as reported to the Railroad Retirement Board were not generally such as to offer a stable substitute for the loss of wages incurred in the severe and fatal injuries. ${ }^{02}$ Where the settlement was small there was little choice but to repay debts and live on the remainder. Even with larger settlements the funds available for investment were rather limited and in the brackets where business mortalities most frequently occur. Some of the investments were admittedly unwise and the possibility of misuse of these all-important funds is always present and serious.

Another deficiency in the FELA approach to damages is that it does not concern itself with the rehabilitation of the disabled to gainful employment. There is great pressure on the worker to claim that he is unable to work in order to collect an adequate award; this is likely to be his attorney's advice. And there is a great temptation on the part of the employer to induce the partially disabled employee to waive his rights to further employment, even at the expense of a larger cash award, rather than face the problem of retraining and re-employing him. Yet only through rehabilitation can the worker regain maximum chances for a happy and productive life. Statistical evidence is difficult to obtain, but the concensus of rehabilitation administrators as sampled by the author is that rehabilitation of injured railroad workers is almost completely neglected. ${ }^{93}$ This loss is probably not made up by any cash element in the FELA settlement and it takes more than just cash to provide for successful rehabilitation.

\section{Trends and Comparisons}

There is little doubt that the passage of workmen's compensation laws brought about an immediate and substantial increase in payments over the awards that had been made under the common law. ${ }^{94}$ Nor is there any doubt that for a number of years railroad workers received markedly less than their neighbors covered under workmen's compensation. Whether the restoration of losses under the FELA has,

\footnotetext{
${ }^{01}$ For example, $\$ 15,000$ in cash awarded to a worker at age 35 is normally equivalent to only $\$ 50$ monthly for the rest of his life if his life expectation was not impaired. This value is based on the 1937 standard annuity table at $2 \frac{1}{2}$ per cent interest.

${ }^{92}$ See I WORK INJuRIes, op. cit. supra note 23 , at 166-176.

${ }^{93}$ I have checked with a number of rehabilitation authorities who have indicated that they rarely if ever have served railroad workers in their institutions.

94 DoDD, op. cit. supra note 24 , at 744 .
} 
to this day, caught up with those under workmen's compensation, is problematical.

Unfortunately, there are no adequate current compilations of Liability Act awards. The deficiency in information, coupled with a tendency on the part of its votaries to exaggerate awards under the Act, ${ }^{95}$ leads to great confusion. The wage losses caused by work injuries have almost trebled since $1940 .{ }^{96}$ Accordingly, a corresponding increase in benefits under the Liability Act would mean no relative improvement at all in the extent to which wage losses are now restored and an increase of greater order would not necessarily indicate that adequacy has been reached. Obviously, tremendous increases in the dollar amounts of payment can be cited, particularly in individual cases. The only valid measure, however, is to consider all payments. Since 1946 , the Railroad Retirement Board has been directed by Congress to "conduct research projects, investigations, and studies with respect to the cause, care, and prevention of, and benefits for, accidents and disabilities ..."97 but it has not collected any further information on this subject. The only available information is from accounts maintained by the Interstate Commerce Commission which are used later as the basis for estimates in this article.

In $1938-40$, railroads were paying annually an average of $\$ 17,690,000$ for cash benefits, medical, administrative and all other costs related to compensation; a gross outlay of 0.86 per cent of payroll. Employers covered under state workmen's compensation laws were paying over one per cent of payroll, as their total outlay in

${ }^{o x}$ At least one major error must be corrected in the article defending the FELA by Richter and Forer. Speaking of the Railroad Board's study this article says ( 36 CoRNerI L. Q. at 224):

641 cases of fatal injuries to railroad workers in r938-40 were studied. Of these, 497 resulted in cash settlements. Of the 497,320 were settled under the F.E.L.A. Suit was filed in only 84. It must be noted that where suit was filed the recovery even to years ago averaged more than $\$ 10,000$... The settlements under the workmen's compensation acts of fatal injuries in intrastate commerce to railroad workers during the same period averaged $\$ 5,187$, or just about half the average recovered under the F.E.L.A.

The source cited is page 98 of the Railroad Board's report.

The facts, as clearly indicated in this source, are that the average for the 84 suit-filed cases was not "more than \$10,000." This average applies to only 33 cases which exclude all FELA suits filed on the deaths of non-operating employees and one train and engine case in which payment of $\$ 500$ or less was made. The average payment for the 50 suit-filed cases of non-operating employees was $\$ 5, \mathrm{r} 82$. The proper average for all 84 suit-filed cases was $\$ 7,087$, but this is before legal expenses were repaid. After repayment of such expenses the average for the 84 cases was approximately $\$ 5,300$, although this is not explicitly shown in the immediate section of the Railroad Board's report cited by Richter and Forer.

Nor can it be concluded that workmen's compensation paid "just about half the average recovered under the F.E.L.A." without dismissing completely the 320 cases settled under the FELA in which suit was not filed and in which the average payment was $\$ 6,4$ Io. The authors were evidently aware of the fact that such cases outweigh the suit-filed. The very paragraph cited earlier begins: "The great preponderance of F.E.L.A. cases are also settled without going to court."

Finally, it is misleading to compare the workmen's compensation average which pertains only to non-operating employees with the average for train and engine service employees whose payments are traditionally higher and would also have been higher under a workmen's compensation law because of their higher earnings. The study cited showed that for non-operating employees the average workmen's compensation payment, expressed in years of full time wages, was about the same as the over-all average after legal cxpenses were deducted.

${ }^{\circ 0}$ The total payroll covered by the railroad retirement and unemployment insurance systems was $\$ 2,273,000,000$ in 1940 and $\$ 6,037,000,000$ in 1951 and the rate of injury increased.

${ }^{\circ 7}$ Railroad Unemployment Insurance Act, 53 STAT. III3 (I939), as amended, 45 U. S. C. $\$ \$ 35 I-367$ (1946) Sec. 12 (q). 
premiums; but this was subject to dividends. Under the Massachusetts compensation law, for example, employers paid about $\mathrm{r} . \mathrm{I2}$ per cent ${ }^{98}$ and about a score of other workmen's compensation laws were as liberal or more liberal than the Massachusetts law. ${ }^{99}$ Moreover, the time loss caused by railroad injuries, as measured by the severity rate, was almost twice that for other industries ${ }^{100}$ which made the relative outlay of the railroads substantially below one half the gross outlay of other employers.

On a net basis, the cash benefits and medical care received by railroad employees came to 0.74 per cent of payroll, before expenses were repaid by the employees, and 0.68 per cent afterward. Under workmen's compensation, benefits and medical care cost 0.72 to 0.74 per cent of payroll in 1940. ${ }^{101}$ Railroad workers, however, lost 2.8 days for every 1,000 hours worked while in all industries the severity rate was $1.466^{102}$ To have repaid the railroad workers about the same percentage of their losses as other workers, the net railroad benefits should have been over 1.3 per cent of payroll instead of 0.68 percent.

Since 1940, the dollar amounts of payment under state compensation laws increased by 176 per cent, but there was a decrease in the per cent restoration of losses. Employers are now paying 0.56 per cent of payroll for workmen's compensation benefits. ${ }^{103}$ The Liability Act, on the other hand, unencumbered by statutory benefit limitations, made relative gains. Nevertheless, the likelihood is that in the aggregate railroads are not repaying an appreciably greater percentage of wage losses than employers covered by workmen's compensation laws.

The Interstate Commerce Commission maintains compilations of the total payments made by railroads as a result of personal injuries. ${ }^{104}$ Unfortunately, the data are incomplete; they show only aggregate payments and do not segregate awards for employee injuries from those involving other persons, primarily passengers.

According to this source, by $195 \mathrm{I}$ the railroads had increased their gross outlay

${ }^{28}$ Arthur H. ReEde, Adequacy of Workmen's Compensation 269 (ig47) shows data from midI912 through r939. The percentages of payroll spent for premiums in the period under study were:

$$
\begin{array}{ll}
1936 & \text { I.21 } \\
1937 & \text { r.I5 } \\
1938 & \text { I.I3 }
\end{array}
$$

The percentages for 1939 and I940 are not available, but it appears likely that they were comparable to the years shown.

${ }^{00}$ Id. at 406 .

${ }^{100}$ See supra note 23.

1014 President's Commission on the Health Needs of the Nation, Building America's Healtu 209, 211 (1952).

${ }^{102}$ The severity rate of railroad injuries was computed by the Railroad Retirement Board for 1938-40. See I Work INJunies, op. cit. supra note 23 , at 59 . The rate for all manufacturing can be found in Annual Reports on Work Injuries in the United States, issued by the Burcau of Labor Statistics. The rate for all industries is less reliable than that for all manufacturing because of sampling difficulties. For most industries other than manufacturing, the rates would tend to be lower than those for manufacturing. See Accident FACTs 26-27 (195I Ed.) for the rates covering all employers reporting to the National Safety Council.

${ }^{103} 4$ President's Commission, op. cit. supra note ror.

${ }^{106}$ In three accounts covering Injuries to Persons. Account number 274 deals with injuries in connection with the maintenance of way and structures; account number 332 , with maintenance of equipment; and account 420 , with transportation. 
for personal injuries by 307 per cent over I940. The rate of increase does not support claims of a miraculous cure of the evils under the FELA which existed in I940. The increase was about average for employer contributions to social insurance and welfare benefits in the same period. According to the United States Department of Commerce data the nationwide increase averaged $33^{6}$ per cent and railroads increased their contributions under the railroad Retirement Act by $35^{8}$ per cent. The ICC reports the railroad injury payments in three categories. Two involve mostly employee injuries as they cover maintenance of way and structures, and maintenance of equipment activities; they show increases in payments of 245 and 294 per cent respectively. Injuries to passengers, trespassers, and employees are combined in the third category, those arising out of transportation, where the increase was 320 per cent. There is some basis for assuming that payments to employees increased at about the same rate as those to passengers. ${ }^{105}$ The increase in payments may, on this basis, be roughly estimated at about 307 per cent.

In the same period, railroad payrolls increased by ${ }^{2} 76$ per cent. ${ }^{106}$ Accordingly, the probable percentage of payroll now being paid by railroads as their total outlay for employee injuries is between I.I and I.3. Railroad payments estimated roughly in this manner probably reached I per cent in 1944 , and climbed to a wartime peak of 1.27 per cent in I945. The payments declined in 1946 to 1.07 , but have since risen to $I .22$ in $195^{\circ}$ and a record of $I .3 I$ in 1951 . The net benefits to employees in I95 $\mathrm{r}$ were probably only $\mathrm{x} .04$ per cent.

However, the relative hazard of railroad work over other employment appears to have even increased. ${ }^{107}$ It is, thus, far from certain that the per cent of wage losses restored to railroad employees is any greater than that restored under workmen's compensation laws. It can certainly be shown that railroad workers are recovering relatively less than under a more adequate compensation law such as that covering federal employees. ${ }^{108}$ The workmen's compensation plan under consideration at the time of the Railroad Board's investigation would have increased the net cash compensation to $\$ 21,500,000$ for the same injuries. Even if it had remained unamended, its benefits would have amounted to approximately 1.5 per cent of payroll. For injuries in $1938-40$ it would have paid higher benefits in 95 per cent of the fatal injuries where the survivors consisted of the worker's widow and children; in more than 80 per cent of the permanent total disability cases; in over 9o per cent of the permanent partial disabilities; and in 75 per cent of the temporary total disabilities. ${ }^{108}$

\footnotetext{
${ }^{105}$ The director of the claims department of a major class $x$ railroad stated, in an interview, that the settlements for employee and passenger injuries had increased at about the same rate.

${ }^{100}$ See supra note 96.

${ }^{107}$ Unfortunately severity rates are not currently available for the railroad industry. The severity rate, however, tends to be correlated with the frequency rates which are available. The railroad frequency rate in $195 \mathrm{I}$ had increased by about $x 6$ per cent over 1938-40; the rate for all manufacturing had increased by only 3 per cent. The relative hazard of railroad employment over all manufacturing may thercfore have increased.

${ }^{108}$ See infra pp. 3I6-3I7.

${ }^{109}$ For a description of the plan which is not necessarily here recommended in full see $I$ WoRK
} 
That is not to minimize the shortcomings under state workmen's compensation laws. Weekly benefit maximums are now limiting compensation levels for a majority of the disabled and over-riding the intended percentage of wage loss restoration. Only eleven jurisdictions pay compensation in death cases to widows for life or until remarriage, and to children until they attain majority. ${ }^{\mathbf{1 1 0}}$ Only 18 jurisdictions provide benefits for life or during the duration of permanent total disability without any dollar maximum. ${ }^{111}$ It is not necessary to go much further to reveal the inadequacy of many state compensation acts. Taken together, the various maximums prevent most state laws from providing adequate protection and shift a major portion of the losses caused by work injuries to the injured, their families, and those who may assume the responsibility to aid them.

But society must look for solutions to its problems, not rationalizations of its shortcomings. In searching through its experience for valid and successful strains from which a proper compensation system might emerge, there soon appear the Canadian compensation systems, long free from the shortcomings of the domestic systems. Canadian systems have pioneered in developing an adequate and integrated remedy including rehabilitation, and these have been elected by railroad workers in that country in preference to liability actions. ${ }^{112}$ There also is the Federal Employees' Compensation Act of 1949 which "pays 75 percent of the monthly salary rate during any period of disability .... ." and provides for monthly compensation at the prescribed percentage up to a maximum of $\$ 525$ per month. ${ }^{113}$ Apart from this monthly maximum, the law does not impose duration or dollar maximums. The average death benefit under this law in I95I was $\$ 33,662$; at that it included some cases in which the only benefit was for funeral expenses. As the average wage of injured employees has been less than $\$ 300$ per month, the $\$ 525$ monthly benefit maximum has not proved restrictive. Only 23 per cent of the injury cases involved a wage between

INJURIES, op. cit. supra note 23 , at $189-191 ; 2$ id. Appendix $F$. For the cost of the plan sce 1 id. C. I2. For a comparison of payments under the Liability Acts in 1938-40 with corresponding payments under the workmen's compensation plan see I id. C. II.

${ }^{110}$ Arizona, District of Columbia, Hawaii, Nevada, New York, North Dakota, Oregon, Washington, West Virginia, U. S. Civil Employees and Longshoremen.

111 Arizona, California, Colorado, Delaware, District of Columbia, Idaho, Massachusetts, Nebraska, Nevada, New York, North Dakota, Ohio, Oregon, Washington, West Virginia, Wisconsin, U. S. Civil Employees and Longshoremen.

${ }^{112}$ Several of the Canadian workmen's compensation laws give railroad workers the option of clecting to come under their provisions. In Alberta, for example, railroad workers have had available an employers' liability act since I908. (The Workmen's Compensation Act, 1908, c. 12, 8 Evw. 7.) In 1928 the Alberta Accident Fund (workmen's compensation) Act (The Workmen's Compensation Act, Accident Fund, c. 5, 8-9 GEo. 5) was amended, permitting railway employees to vote on whether or not they wished to come under its scope. (The Workmen's Compensation Act (Accident Fund) Amendment Act 1928, c. 38, 18 Geo. 5). The Maintenance of Way Employees of the Canadian Pacific Railway promptly elected to come under the workmen's compensation act. In $194 \mathrm{I}$ the Brotherhood of Railway Trainmen, and in 1942 the Order of Railway Conductors, elected workmen's compensation coverage. As a result, the 1908 (Employers' Liability) Act, although never repealed, has become inoperative as all industries hitherto covered by it have been brought within the scope and cxclusive jurisdiction of the Accident Fund Act. In Saskatchewan, the Brotherhood of Locomotive Firemen and Engincmen came under workmen's compensation on April I, 1948, and the Brotherhood of Railroad Signalmen was admitted by an Order in Council of February 20, $195 \mathrm{I}$.

${ }^{113}$ Annual Report of the Bureau of Employees' Compensation 4 (1950). 
$\$ 300$ and $\$ 350$, and in only 7 per cent was the wage above $\$ 35^{\circ}$. The high maximum thus makes it possible to keep benefits at the recognized proportion of the wage, without change in statutory limit. Its cost of $0.3 \mathrm{I}$ per cent of payroll in relation to the severity rate of 0.66 suggests that if these standards were applied to the railroad industry the cost would be about 1.5 per cent, an amount that obviously exceeds the present payments under the FELA. Its administrative cost has been reduced to less than 4 per cent of benefits ${ }^{114}$ compared with 26 per cent of gross cash payments in the railroad industry.

Comparisons of payments under the Liability Act and under workmen's compensation, however, tend to obscure a far more important point-that the absolute magnitude of payments for compensation under both systems is insufficient. Both compensation measures were generated in the same climate-a severe one when too much attention was focused on protecting industry against liability.

The setting in which common law compensation was conceived has been described by President Taft, who observed that "the old rules of liability under the common law were drawn by men imbued with the importance of preserving the employers from burdensome or unjust liability." 115 The obstacles in the way of workmen's compensation are recalled by Justice Cardozo in his comments on the ruling ${ }^{116}$ that held the New York Workmen's Compensation Act of Igro to be unconstitutional: $:^{117}$

The act required an employer to contribute to an insurance fund for the benefit of employees injured in the course of their employment. Property was held to have been taken without due process when a contribution was thus levied regardless of the employer's fault ... . On the one hand, the right of property, as it was known to the fathers of the republic, was posited as permanent and absolute. Impairment was not to be suffered except within narrow limits of history and precedent. No experiment was to be made along new lines of social betterment.

Since those early days, both compensation systems have failed to keep pace with the nation's changing social values and its expanding economy. A network of social security and related benefits has grown up surrounding and overshadowing workinjury compensation. The vast growth of pension plans, disability insurance, hospital, surgical, medical, and other benefits has extended the responsibility of many employers to providing protection against nonoccupational disability and for the worker's family. Work-injury compensation has remained impoverished while the other social insurance measures have received more prominent attention and more liberal allocation of money. A study of "fringe benefits" made by the Chamber of Commerce shows that while employers are paying only 0.6 per cent of payroll

\footnotetext{
114 Per cent administrative costs to benefit payments for $195 \mathrm{I}$ obtained by inquiry addressed to the Bureau of Employees' Compensation. The percentage for 1950 was 4.5. Id. at ro.

${ }^{115}$ Message to Sixty-second Congress under date of February 20, 1912, transmitting the report of the (Sutherland) Employers' Liability and Workmen's Compensation Commission. SEN. Doc. No. 338, 62d Cong., $2 d$ Sess. 7 (rgrz).

${ }^{110}$ Ives v. South Buffalo Ry., 201 N. Y. 27 I, 94 N. E. 43 I (IgrI).

${ }^{117}$ Cardozo, The Growth of the Law $71-72$ (I927); also Selected Writings of Benjamin Nathan Cardozo 217 (Hall ed. 1947).
} 
for workmen's compensation, they are now spending 8.3 per cent on pensions, and related private and social insurance programs. ${ }^{118}$

So long as the FELA-workmen's-compensation controversy is restricted to a sterile debate between two ailing systems, the path to progress is obscured. Once it is recognized that there should be a substantial increase in the allocation for security against occupational hazards, it becomes evident that a correlated reform is to assure that compensation will be not only liberal in amount, but equitably distributed among the disabled. This requires workmen's compensation principles and their exclusive application.

\section{$\mathrm{V}$}

\section{ConcLusions}

Much of the history of work-injury compensation suggests that the security which society grants workers against occupational hazards is a function of the esteem in which it holds them. The course of compensation also suggests that society has held the entire matter in very low esteem. The cripple and the widow have ever been regarded as unfortunates whose condition had best not be too closely contemplated. The crux of the problem is not whether the railroads pay a little more, or less, than employers under a typical workmen's compensation law. Compensation must be increased in virtually all jurisdictions to assure an equitable sharing of the burden of work-injury costs. A society that is normally generous and even prodigal is morally bound to bring its compensation practices into closer conformity with other forms of remuneration, so that less of the burden is visited on the disabled, to relieve them of the cruel and unnecessary tragedy which often accompanies injury.

The railroad compensation system cannot overcome its inherent deficiencies: an improper standard of eligibility, an unconscionably faulty procedure, and" a method of payment that does not provide the necessary assurance of security. As progress is made toward a more adequate remedy, it is unthinkable that the Liability Act's pattern of payment can be continued.

Proposals to graft a workmen's compensation election onto the FELA beg the question. If the workmen's compensation law is set at a low level, it would be merely a stop-gap measure that would maintain most of the existing evils, ameliorating them to soften criticism, but perpetuating the improper allocation of compensation. An elective system is almost bound to impose a "floor of protection" concept on its workmen's compensation component, rather than an adequate protection concept.

In much the same position are proposals to cover work injuries under a broad social insurance system and to allow for suits in negligent injuries. This is actually happening under the railroad social insurance system and the liability laws. Here, too, the benefits tend to be very modest. A combined social insurance and Liability Act program means realistically that a much lower level of benefit would be paid to most people, to propitiate the vested interests favoring a suit system. It is

${ }^{118}$ Sce supra note ro3. 
inconceivable that a really adequate and sound compensation system can ever be developed by any other, plan except that of making the payments bear a direct relation to the lost wages and severity of disability for every injury. If such a workmen's compensation law is developed, continuation of the FELA is unnecessary.

It would of course be unwise for railroad workers to accept less protection than they now have or to accept a rigid benefit framework that would soon become inadequate. But it would be less than rational to reject a practical solution that not only would increase their cash compensation but would offer an assured, equitable remedy, which they lack today. Such a law is here proposed.

Having developed, over eighteen years, one of the most comprehensive social insurance systems in the nation, railroad workers now have an almost ideal base for the kind of compensation law that was originally hoped for and thus far only rarely attained. The vehicle which has served to provide old age, survivors, disability and unemployment insurance with economy, efficiency, and only negligible need for litigation can be the base for an exemplary workmen's compensation law. ${ }^{119}$ For the first time in this country, compensation can be properly integrated into a comprehensive system of social insurance. It would be tragic if an industry faced with this challenging possibility would choose to retain a "cruel and wasteful" method of compensation that has only continued inadequacy and disorder to offer.

${ }^{110}$ Over a period of $x 8$ years, the Railroad Retirement Board has demonstrated that under a soundly administered social insurance program the need for litigation and appeals is negligible. The benefits have been awarded automatically as had originally been intended for workmen's compensation. The cost of administration has been exceedingly little and the quality of administration has been excellent. 